Japanese Journal of Transfusion Medicine, Vol. 40. No. 3 40(3) : 488-492, 1994

末梢血幹細胞移植の現状と問題点

九州大学医学部第一内科

原 田 実 根

はじめに

同種および自家骨髄移植 (allogeneic bone marrow transplantation, allo-BMT; autologous BMT, ABMT) は骨髄造血幹細胞の移植であるが，造血幹細 胞は骨髄だけでなく末梢にもごく少数ながら存在する ことが古くから知られている。この末梢血幹細胞 (peripheral blood stem cells, PBSC) は，骨髄抑制 的な化学療法後の造血回復期に一過性ながら著明に増 加する. そこで, この PBSCを大量に採取保存し，骨 髄破壊的治療後の血液学的再構築に利用する末梢血幹 細胞移植 (PBSCT) が, allo-BMT, ABMT に次ぐ第 3 の造血幹細胞移植として最近注目されている ${ }^{122)}$.

1.PBSCの動員および採取

PBSC は化学療法後の造血回復期に骨䯣から末梢に 動員 (mobilization)される.PBSC 採取のためには, 連続血球分離装置を用いて数回のアフェレーシスを実 施し, 6 10l の処理血液量から大量の末梢血単核細胞 （通常 $10^{10}$ 個以上）を選択的に採取する。採取された PBSC の指標には, in vitro で測定可能な顆粒球/単球 系前駆細胞である CFU-GM が利用される。最近では, 末熟な造血幹細胞マーカーとされる CD34陽性細胞が PBSC の指標として利用されつつある.

PBSC を効率的に採取するための化学療法は特定さ れていないが,一般的には骨髄抑制がある程度強く(た とえば好中球 $<500 / \mu l$, 血小板 $<50,000 / \mu l)$, 急速な 造血回復がみられる場合に十分量の PBSC 採取が可 能である。われわれの経験では, PBSC 採取の至適タ イミングは白血球が nadir から回復して $1,000 / \mu l$ を 越える時期から約 10 日間で, 白血球が $4,000 / \mu l$ を越え ると含まれる PBSC は急速に減少する。さらに，白血 球と血小板が同調して回復する場合にもっとも効率よ く採取できる3).

PBSC の採取効率を高めるために, 化学療法後の造 血回復期に造血性サイトカインを併用してPBSC プールを増大させる方法が積極的に実施され, その有 効性が明らかにされている。たと艺，Gianni ら゙) cyclophosphamide 大量 $\left(7 \mathrm{~g} / \mathrm{m}^{2}\right)$ 投与後に GM-CSF $(5.5 \mu \mathrm{g} / \mathrm{kg})$ を投与し，また Elias ら5)は乳癌に対する
寛解導入療法 (AFM) 後に GM-CSF $(5 \mu \mathrm{g} / \mathrm{kg})$ を投 与し，それぞれ化学療法単独よりも有意に高いCFU. GM 採取量を得ている。われわれも急性白血病に対す る寛解地固め療法（中等量の Ara-C に mitoxantrone または etoposide 併用) 後に G-CSF ( $5 \mu \mathrm{g} / \mathrm{kg}$ )を併用 する PBSC mobilization を検討し, CFU-GM 採取量 が化学療法単独の場合より有意に高い成績を得てい $ろ^{3)}$. 島崎 $ら^{6)}$ も同様の検討を行い, 良好な成績を報告 している.一方, IL-3と GM-CSF の PBSC 動員促進効 果が固型腫瘍で検討され, PBSC 採取効果はIL-3+ GM-CSF がもっとも高く, ついで GM-CSF, 化学療法 単独が最低であったといら7).

PBSC mobilization は, 造血回復期ではなく “steady state”に造血性サイトカインを投与すること によって可能なことが最近明らかにされている，たと えば, Duhrsen ら ${ }^{8)}$ は G-CSFの 5〜 7 日間投与によ り，CFU-GM だけでなく赤血球系前駆細胞 (BFU-E) さらに骨髄系前駆細胞 (CFU-Mix) も未梢血中に動員 されらること明らかにしている。われわれも同様の成 績(表 1 )を得ており ${ }^{9)}$ ，G-CSFによって顆粒球系以外 の前駆細胞も動員されらることは, G-CSF の作用機序

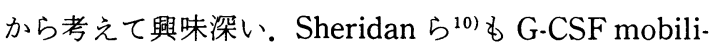
zationの有効性を明らかにし, 採取されたPBSC の移 植によってきわめて速やかな移植後の血小板回復を報 告している. その他, IL-3+GM-CSF, IL-1, IL-2, stem cell factor (SCF) などの有効性を示唆する成績が相次 いで報告されており, 今後 cytokine mobilizationは 大きく進展するものと予想される.

\section{PBSC の簡便凍結法}

造血幹細胞の凍結法は, これまで凍害保護液として $10 \% \mathrm{DMSO}$ を用い，プログラムフリーザーによる rate-controlled freezing（たとえばー $1^{\circ} \mathrm{C} / \mathrm{min}$ )を行 い，液体窒素中に保存する方法が一般的であった。し かし, 実際的な問題として, PBSCを冷凍保存する症 例が増加すると, 冷凍保存用スペースや液体窒素消費 量などが思わぬ障害となる。

そこで, PBSCの簡便冷凍保存法の検討を行った。 具体的には, 凍害保護剤として種々の濃度の hydrox- 
表 1 PBSC 採取：化学療法単独と化学療法 $+\mathrm{G}-\mathrm{CSF}$ の比較

\begin{tabular}{l|c|c|c|c}
\hline \multirow{2}{*}{} & \multicolumn{2}{|c|}{ cytotoxic $(\mathrm{n}=10)$} & \multicolumn{2}{c}{ cytotoxic $/ \mathrm{G}-\mathrm{CSF}(\mathrm{n}=12)$} \\
\cline { 2 - 5 } & 1 st cycle & 2 nd cycle & 1 st cycle & 2 nd cycle \\
\hline No. of MMC $\left(10^{8} / \mathrm{kg}\right)$ & 2.48 & 2.87 & 2.55 & 6.74 \\
No. of CFU-GM $\left(10^{4} / \mathrm{kg}\right)$ & 5.39 & 3.72 & 3.18 & 17.5 \\
No. of BFU-E $\left(10^{4} / \mathrm{kg}\right)$ & 3.21 & 2.77 & 3.31 & 12.9 \\
\hline
\end{tabular}

同一の化学療法を 2 cycle 行い, その造血回復期に PBSC を採取する (cytotoxic), 同様の PBSC 採取 を行い, 2 nd cycie 後の造血回復期に G-CSF ( $5 \mu \mathrm{g} / \mathrm{kg})$ の併用投与を行う (cytotoxic/G-CSF), 值は 中央値を示す。（文献帛より引用）

表 2 簡便凍結法による PBSC の長期保存成績

\begin{tabular}{l|l|l|l|l|l}
\hline & \multicolumn{5}{|c}{ Storage periods (months) } \\
\cline { 2 - 6 } & 1 & 3 & 5 & 12 & 18 \\
\hline Cell recovery (\%) & $95 \pm 10$ & $95 \pm 6$ & $81 \pm 9$ & $80 \pm 11$ & $79 \pm 10$ \\
Trypan blue viability (\%) & $94 \pm 7$ & $90 \pm 7$ & $91 \pm 5$ & $88 \pm 5$ & $86 \pm 7$ \\
CFU-GM recovery (\%) & $91 \pm 16$ & $76 \pm 13$ & $70 \pm 11$ & $71 \pm 10$ & $70 \pm 11$ \\
BFU-E recovery (\%) & $98 \pm 10$ & $95 \pm 11$ & $90 \pm 7$ & $86 \pm 9$ & $84 \pm 10$ \\
\hline
\end{tabular}

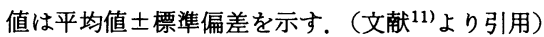

yethyl starch（HES）とDMSO の混合液を用い, プ ログラムフリーザーを使用せずにー $80^{\circ} \mathrm{C}$ で涷結保存し た。造血能の指標として CFU.GM と赤血球系幹細胞 （BFU-E）を用いて検討した結果，HES $6 \%$, DMSO $5 \%$, Albumin $4 \%$ の凍害保存液を用いた場合に, 細 胞回収率 $95 \pm 4 \%$, trypan blue 生存率 $90 \pm 7 \%$, CFUGM 回収率 $74 \pm 4 \%, B F U \cdot E$ 回収率 $82 \pm 7 \%$ ( 3 力月 保存)ともっとも良好な成績が得られた ${ }^{11}$. この簡便法 によって，18カ月の凍結保存でも CFU-GM 回収率 $70 \%$ と良好な長期保存が可能であった（表 2 ).

\section{PBSCT の臨床応用}

PBSCT の本格的な臨床応用は1980年代後半になっ てからであるが，全世界で既に1,500例以上，わが国で も250以上実施され, 実施症例数は急速に増加しつつあ る。対象疾患としては，急性骨髄性白血病 (AML), 急性リンパ性白血病 (ALL), 慢性骨髄性白血病 (CML), Hodgkin 病 (HD), 非 Hodgkinリンパ 腫
(NHL), 多発性骨髄腫など造血器悪性腫瘍が多いが, 最近では乳がん, 卵巣がん, 神経芽腫など固型腫瘍に も積極的に試みられている. 図 1 にわれわれが行って いる PBSCTを利用する造血器腫瘍の治療方式を示 す.

\section{PBSCT の実際}

PBSCT の具体的症例を図 2 に示す. 症例は 25 歳, 男 性の ALL で, 初回寛解の地固め療法後の造血回復期 にPBSCTを採取した. conditioning として busulfan $16 \mathrm{mg} / \mathrm{kg}$, etoposide $30 \mathrm{mg} / \mathrm{kg}$, Ara-C $12 \mathrm{~g} / \mathrm{m}^{2}$ (BEA 療法）を施行後, $4.2 \times 10^{5} / \mathrm{kg}$ の CFU-GM を移植し た. 移植後白血球および血小板は急速に減少したが, 9 日目には白血球および顆粒球ともに $1,000 / \mu l$ を越 え，血小板輸血はわずか 2 回のみで，15日目には血小 板も $100,000 / \mu l$ 以上となり生着が確認された。

顆粒球が生着レベルである $500 / \mu l$ 以上に回復する のに, allo-BMT やABMT では $3 \sim 4$ 週を要するが,

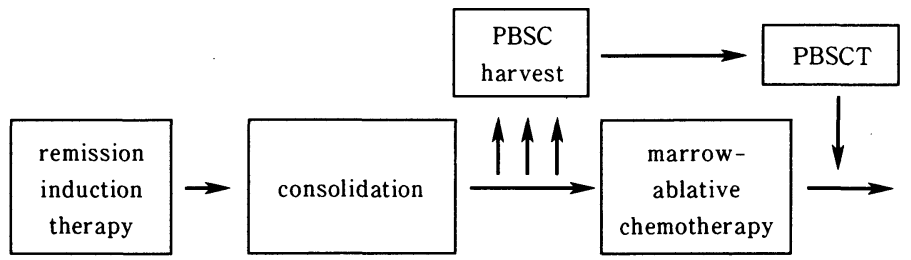

図 1 未梢血幹細胞移植 (PBSCT) を利用する造血器悪性腫瘍の治療方式 


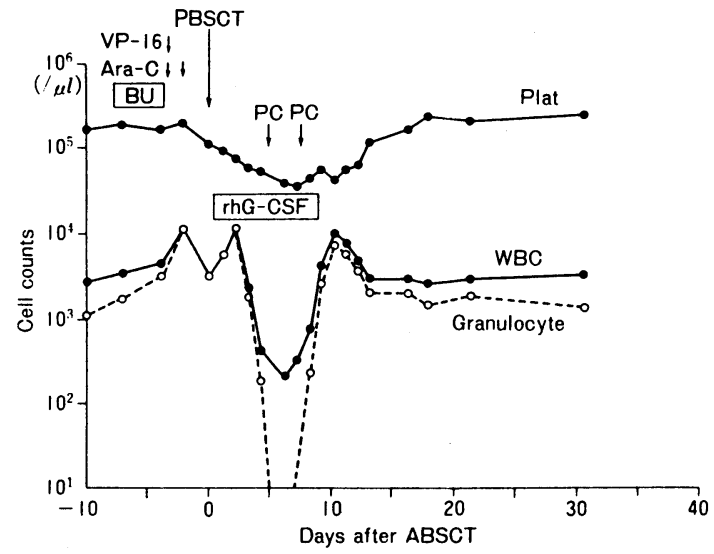

図 2 PBSCT の臨床経過(25歳, 男性, ALL/第 1 寛 解期)

PBSCT では遅くとも 2 週以内に生着が得られる。乙 たがって, PBSCT は厳重な無菌管理を必要とせず, 普 通病室で実施可能であり，造血回復遅延に伴う重大な 合併症や感染症のリスクもきわめて低い.このように， PBSCT ではきわめて速やかな造血回復が多くの報告 で確認されており，PBSCTのもっとも有利な点と考 えられる.その理由は, PBSCT は ABMT に比較して 移植される造血前駆動がきわめて多いためと考えられ る。したがって，迅速な造血回復を得るためには，移 植される CFU-GM 量として $1 \times 10^{5} / \mathrm{kg}$ 以上 ${ }^{3)}$ ，CD34 陽性細胞数として $2 \times 10^{6} / \mathrm{kg}$ 以上 ${ }^{12)}$ が必要とされる。

5. 移植成績
造血器悪性腫瘍に対するPBSCT の主要な成績を 表 3 に示す ${ }^{11}$. AML はPBSCT がもっとも多く実施さ れている疾患であるが，第 1 寛解期の移植では 30〜46\%が寛解を維持し, disease free survival(DFS) は移植後 2 年で $35 \%$ 前後と予想されている。治療失敗 の原因はほとんど白血病再発で，再発率は $54 ７ 0 \%$ と allo-BMT の場合に比べて明らかに高い，以上の成績 は, AML に対する ABMT の成績とほとんど変わら ないが, ABMT に比べて造血回復が早い. 入院期間が 短い，移植関連死亡がきわめて少ない，など PBSCT の有利な点が指摘されている。

ALL に対する PBSCT の報告は少ない，高上らは， high risk の急性白血病 (ALL が3/4) や悪性リンパ腫 に対して，MCNUを中心とする超大量化学療法を用 いてPBSCTを積極的に行っており，寛解維持 $50 \%$ 以 上と通常の化学療法より良好な成績を報告している。

CML は通常化学療法では治癒が困難で, allo-BMT が唯一の治癒的治療法と位置づけられている。最近， 未治療時の末梢血単核細胞をPBSCT として用いる PBSCT がCML に試みられている。とくに慢性期の CML に対するPBSCT では，移植後の interferon 療 法の併用が注目される。

悪性リンパ腫はABMT の有効性が明らかにされて いる造血器腫瘍であるが, 腫瘍細胞の骨髄浸潤, 骨盤 部照射の既往, 骨髄低形成などの理由で自家骨髄採取 が困難な症例を対象にPBSCT が試みられた。 Kessinger $ら^{13)}$, Körbling ら ${ }^{14)}$ は上記の理由で ABMT が適

表 3 造血器腫瘍に対する PBSCT の成績

\begin{tabular}{l|l|l|r|r|r|c}
\hline 報告者 & 疾患 & $\begin{array}{l}\text { ABSCT } \\
\text { 時の状態 }\end{array}$ & 患者数 & $\begin{array}{c}\text { CCR で生存 } \\
\text { (\%) }\end{array}$ & 再発 (\%) & $\begin{array}{c}\text { 経過観察 } \\
\text { (月) }\end{array}$ \\
\hline Reiffers & AML & 2 nd CR & 11 & $4 / 10(40)$ & $6 / 10(60)$ & 24 \\
Korbling & AML & 1 st CR & 26 & $11 / 24(46)$ & $13 / 24(54)$ & $3 \sim 55$ \\
Szer & AML & 1 st CR & 20 & $6 / 20(30)$ & $14 / 20(70)$ & 24 \\
Reiffers & CML & AP/BC & 47 & $12 / 36(33)$ & $22 / 36(61)$ & $7 \sim 26$ \\
Meloni & CML & CP & 26 & $18 / 22(82)$ & $4 / 22(18)$ & $14 \sim 55$ \\
Kessinger & HD & refractory & 24 & $7 / 24(29)$ & & $3 \sim 70$ \\
& NHL & refractory & 16 & $8 / 16(50)$ & & $3 \sim 36$ \\
Korbling & HD & advanced & 12 & $7 / 11(64)$ & & $6 \sim 93$ \\
Kotasek & NHL & poor risk & 16 & $7 / 16(44)$ & $9 / 16(56)$ & $2.5 \sim 28$ \\
Fermand & MM & refractory & 8 & $2 / 8(25)$ & & $15 \sim 16$ \\
Ventura & MM & refractory & 11 & $4 / 11(36)$ & & $3 \sim 7$ \\
\hline
\end{tabular}

CR : 完全寛解, AP : accelerated phase, BC : 急性転化, CP : 慢性期, refractory : 不応性, advanced : 進行期, poor risk : untreated or treated poor risk patients, CCR : CR 維持 
表 4 造血器悪性腫瘍に対する PBSCT の治療成績（自験例）

\begin{tabular}{|c|c|c|c|c|c|c|}
\hline Disease & $\begin{array}{l}\text { Status at } \\
\text { ABSCT }\end{array}$ & $\begin{array}{l}\text { No. of } \\
\text { patients }\end{array}$ & $\mathrm{RRM}^{\mathrm{a})}$ & Relapse & $\begin{array}{l}\text { Alive in } \\
\mathrm{CCR}^{\mathrm{b})}\end{array}$ & $\begin{array}{l}\text { Median } \\
\text { follow-up (mo) }\end{array}$ \\
\hline \multirow[t]{3}{*}{ ANLL } & 1 st $\mathrm{CR}$ & 17 & 0 & 6 & 11 & $14(4-34)$ \\
\hline & 2 nd CR & 5 & 0 & 3 & 1 & $9(4-32)$ \\
\hline & Advanced & 6 & 0 & 4 & 1 & $6(2-52)$ \\
\hline \multirow[t]{3}{*}{ ALL } & 1 st CR & 12 & 0 & 6 & 6 & $13(1-50)$ \\
\hline & 2 nd CR & 6 & 0 & 5 & 1 & $10(8-25)$ \\
\hline & Advanced & 2 & $2^{c)}$ & $\mathrm{NE}^{\mathrm{d})}$ & 0 & $\mathrm{NE}^{\mathrm{d})}$ \\
\hline \multirow[t]{3}{*}{ NHL } & 1 st CR & 5 & 0 & 2 & 3 & $14(3-34)$ \\
\hline & 2 nd CR & 1 & 0 & 0 & 1 & 5 \\
\hline & Advanced & 5 & 0 & 3 & 2 & $5(3-40)$ \\
\hline \multicolumn{5}{|c|}{ a) Regimen related mortality } & \multicolumn{2}{|c|}{ (As of Sept. 1. 1993) } \\
\hline \multicolumn{7}{|c|}{ b) Continuous complete remission } \\
\hline \multicolumn{7}{|c|}{ Cardiac failure and veno-occlusive disease of the liver } \\
\hline
\end{tabular}

応でないと判断された治療不応性あるいは進行期の HD NHLに対してPBSCTを実施し, DFS 50〜 60\%前後と期待できる成績を報告している。一方， Kotasek ら ${ }^{15}$ ) , poor risk の NHLにPBSCT を実施 し，16例中 7 例が寛解生存中といら成績を報告してい る.

われわれも AML, ALL, NHL に対するPBSCTを 積極的に実施している ${ }^{16}$.これまでの成績(表 4 )では, AML およびALLの第 1 寛解期の移植で 50 〜 $60 \%$ に 寛解持続が得られている. DFS は AML で約 $60 \%$, ALL で約 $40 \%$ と観察期間は短いものの期待できる成 績と考えられる: 一方, 第 2 寛解期や再発時の移植で は70\%以上に再発がみられている。したがって, PBSCT は第 1 寛解期の AML およびALLに対する 有力な寬解後療法として積極的に試みる価值があると 思われる．NHLに対するPBSCT はまだ症例数が少 ないが，期待できる成績が得られつつあり，今後症例 の集積が必要である。治療に密接に関連した早期死亡 は59例中わずか 2 例であり, 寛解期移植では 1 例もな く, PBSCT はきわめて安全性の高い治療法といえる. 最近, 進行性あるいは予後不良の MM に対しても PBSCT が積極的に試みられている。その他, 乳癌, 卵 巣癌, 神経芽腫などの固型腫瘍に対する PBSCT も注 目されている。

おわりに

PBSCT は, 治療理念はABMT と同じであるが, 両 者を比較すると有利な点が多く（表 5 ），ABMTに替 りらる造血幹細胞移植と考兄られ, 今後急速に増加し ていくものと予想される．今後検討すべき重要な課題
表 5 PBSCT の有利な点, 不利な点

\begin{tabular}{|c|c|c|}
\hline & 有利な点 & 不利な点 \\
\hline 自家骨䯙移植と & $\begin{array}{l}\text { 造血回復が早い } \\
\text { 腫場細胞の混入が少な } \\
\text { い? } \\
\text { PBSC採取に全身麻酔 } \\
\text { を必要としない }\end{array}$ & $\begin{array}{l}\text { 十分量の PBSC採取に } \\
\text { 頻回の apheresisが必要 }\end{array}$ \\
\hline $\begin{array}{l}\text { 通常化学療法と } \\
\text { 比較して }\end{array}$ & $\begin{array}{l}\text { 骨䯣抑制を考虙しない } \\
\text { dose-escalation が可能 } \\
\text { 造血回復が早い } \\
\text { 治療期間の短縮 }\end{array}$ & $\begin{array}{l}\text { 十分量のPBSC採取に } \\
\text { 頻回の apheresis が必要 } \\
\text { dose-escalationによる } \\
\text { 治療関連死の可能性 }\end{array}$ \\
\hline
\end{tabular}

としては，1）純化したPBSC（たとえばCD34陽性細 胞）の移植，2）PBSC の ex vivo 増殖，3）PBSC に よる同種移植，4）遺伝子治療における PBSC の利用, などが考兄られ，今後の研究の進展が望まれる。

\section{文献}

1) 原田実根：自己末梢血幹細胞移植. 癌と化学療法, $20: 2097-2107,1993$.

2) Craig, J.I.O., Turner, M.L. and Parker, A.C.: Peripheral blood stem cell transplantation. Blood Review, 6: 59-67, 1993.

3) Teshima, T., Harada, M., Takamatsu, Y., et al. : Cytotoxic and cytotoxic/G-CSF mobilization or peripheral blood stem cells anda their autografting. Bone Marrow Transplant, $10: 215$ $-220,1992$.

4) Gianni, A.N., Bregni, N., Stern, A.C., et al.: Granulocyte-macrophage colony-stimulating factor to harvest circulating haemopoietic stem cells for autotransplantation. Lancet, 2: 580 
$-584,1989$.

5) Elias, A.D., Ayash, L., Anderson, K.C., et al. : Mobilization of peripheral blood progenitor cells by chemotherapy anda granulocytemacrophage colony-stimulating factor for hematologic support after high-dose intensification for breast cancer. Blood, 79 : 3036-3044, 1992.

6) Shimazaki, C., Oku, N., Ashihara, E., et al.: Collection of peripheral blood stem cells mobilized by high-dose Ara-C plus VP-16 or aclarubicin followed by recombinant human granulocytêcolony stimulating fator. Bone Marrow Transplant, $10: 341-346,1992$.

7) Brugger, W., Bross, K., Frish, J., et al. : Mobilization of peripheral blood progenitor cells by sequential administration of interleukin- 3 and granulocyte-macrophage colony-stimulating factor following polychemotherapy with etoposide, ifosfamide, and cisplatin. Blood, 79 : 1193-1200, 1992.

8) Duhrsen, U., Villeval, J.L., Boyd, J., et al. : Effects of recombinant human granulocytecolony stimulating factor on haemopoietic progenitor cells in cancer patients. Blood, 72 : 2074-2081, 1988.

9) Teshima, T., Harada, M., Takamatsu, Y., et al. : Granulocyte colony-stimulating factor (G$\mathrm{CSF}$ )-induced mobilization of circulating haemopoietic stem cells. Br. J. Haematol., 84 : 570-573, 1993.

10) Sheridon, W.P., Begley, C.G., Juttner, C.A., et al. : Effect of peripheral blood progenitor cells mobilizaed by filgrastim (G-CSF) on platelet recovery after high-dose chemotherapy. Lancet, 339 : 640-644, 1992.

11) Makino, S., Harada, M., Akashi, K., et al. : A simplified method for crypreservation of peripheral blood stem cells at $80^{\circ} \mathrm{C}$ without ratecontrolled freezing. Bone Marrow Transplant, 8: 1-6, 1991.

12) To L.B.: Mobilizing and collection blood stem cells. In : Gale, R.P., Henon, P. and Juttner, C.A., eds., Blood Stem Cell Transplants, in press, 1993.

13) Kessinger, A., Armitage, J.O., Smith, D.M., et al. : High-dose therapy and autologous peripheral blood stem cell transplantation for patients with lumphoma. Blood, 74 : 1260-1265, 1989.

14) Kprblin, M., Holle, R., Haas, W., et al. : Autologous stem cell transplantation in patients with advanced Hodgkin's disease and prior radiation to the pelvic site: J. Clin. Oncol., 8: 978-985, 1990.

15) Kotasek, D., Sagem R.E., Juttner, C.A., et al. : Autologous transplantation in non-Hodgkin's lymphoma using high-dose cyclophosphamide mobilized blood stem cells : The Adelaide experience. Int. Cell. Clonig., 10(Suppl. 1) : 129-134, 1992.

16）谷口修一, 原田実根, 牧野茂隆, 他：自己末梢血幹 細胞移植一成人例における検討. 臨床血液, 33 : 945-949, 1992. 